\title{
Identification and Abundance of Plant-parasitic Nematodes Associated with Amenity Trees in the University of Port Harcourt, Rivers State, Nigeria
}

\author{
${ }^{1}$ OSENI, L; *1TANIMOLA, AA; ${ }^{1}$ WOKOMA, EC; ${ }^{2}$ OLADELE, AT \\ ${ }^{I}$ Department of Crop and Soil Science, ${ }^{2}$ Department of Forestry and Wildlife Management, Faculty of Agriculture, University of Port \\ Harcourt, Choba, Rivers State, Nigeria \\ *Corresponding AuthorEmail: tanimoladebo@yahoo.com; Other AuthorsEmail: qlatifatoseni@gmail.com; \\ ekanem.wokoma@uniport.edu.ng; adekunle.oladele@uniport.edu.ng
}

\begin{abstract}
Plant-parasitic nematodes contribute to unnoticeable damages which lead to gradual decline in the values and eventually death of amenity trees. Identification of these nematode pests is vital for their effective management. Reconnaissance survey was carried out to identify amenity tree species present in the University of Port Harcourt (UNIPORT). Composite bulked soil and root samples (126) were collected from amenity trees in UNIPORT and nematode pests were extracted from samples using modified Baerman method. The nematode pests were identified and their populations determined using standard procedures. Relative importance value (RIV) and diversity indices were calculated with appropriate software. Data were processed using descriptive statistics and with analysis of variance. 38 tree species were identified in UNIPORT belonging to 20 families. Terminalia mantaly, Cocos nucifera and Terminalia catappa with RIVs of 15.1, 9.35, and 9.12 respectively were the three most important amenity trees in UNIPORT. Fifteen nematode pest genera; Helicotylenchus, Aporcelaimus, Tylenchulus, Meloidogyne, Scutelonema, Pratylenchus, Tylenchus, Rotylenchoides, Criconema, Hemicyliophora, Trichodorus, Mesodorylaimus, Heterodera, Paratylenchus and Longidorus were associated with 21 of the amenity trees. The three most important nematode pest genera were Helicotylenchus. Tylenchulus and Aporcelaimus with RIVs of 42\%, 16\% and 5.34\%, respectively. Helicotylenchus (RIV 45.41\%) and Tylenchulus (RIV 30\%) were the most important plant-parasitic nematode genera in the soil and roots of amenity trees, respectively. Helicotylenchus, Tylenchulus and Aporcelaimus were the three most important plant-parasitic nematode genera associated with amenity trees in UNIPORT.
\end{abstract}

DOI: https://dx.doi.org/10.4314/jasem.v24i11.18

Copyright: Copyright $($ C 2020 Oseni et al. This is an open access article distributed under the Creative Commons Attribution License (CCL), which permits unrestricted use, distribution, and reproduction in any medium, provided the original work is properly cited.

Dates: Received: 25 January 2020; Revised: 05 November 2020; Accepted: 14 November 2020

Keywords: Amenity trees, Diversity indices, Identification, Nematode pests, Survey

Trees that are not grown or managed for their value as timber, but they also provide other benefits or values are amenity trees (Kraxner et al., 2003; Haysom and Murphy, 2003; Cullen, 2007). Some examples of amenity trees include urban trees found in parks and other open space, or lining the sides of streets, railways, rivers and canals, and in gardens (Olujobi, 2016). Amenity value of trees means how highly the trees are regarded by the community as part of the local landscape. Agbelade et al. (2016) reported the environmental benefits derived from amenity trees to include; purification of air, wind break, provision of shade, beautification, income generation from sales of firewood, provision of relaxation parks and gardens. A tree provides many benefits for the urban dwellers, such as environmental, economical and socio-cultural (Kraxner et al., 2003; Jim and Chen, 2009; Onyekwelu and Olaniyi, 2012). The presence of tree is considered essential in improving the quality of life and wellbeing of city dwellers. In cities, trees have been considered to fulfil a primarily ornamental purpose; however, they also perform other important functions, such as their use for recreation (Gunderson et al., 2006), their role as a link between man and nature (Aldous, 2007), and their contribution to the general well-being of residents in the cities (Dwyer et al., 2000). In West Africa, parks and recreation centres planted with various amenity trees serve as small business centres, community meeting place, religious worship centres and shades for groves in some urban and peri-urban centres (Fuwape and Onyekwelu, 2011). Trees have the potential to create different kinds of social spaces (William, 2008). Trees are culturally and spiritually important in many societies (Omura, 2004; Hall et al., 2011). Individuals and organizations maintain large tree registries (Van Pelt, 2001) and government agencies maintain parks and reserves dedicated to the sustainability of exceptionally large trees (James et al., 2012). There are several pests affecting the growth and development

*Corresponding Author Email: tanimoladebo@yahoo.com 
of trees, it varies from fungal, bacterial, nematode pest infections and at times severe insect damages (Khan, 2012). Some tree species are more susceptible to infestation than others. Gmelina is an example of a tree species susceptible to insect attack and diseases from different pathogens which might limit expansion (Dvorak, 2004). However, least consideration has been given to nematode pests of trees because the damage cause by them seems indistinctive and not easily recognised (Khan, 2012). Globally, plant-parasitic nematodes (PPNs) have been reported as one of the major biotic banes to the growth and development of trees (Hagan, 2005; El-Sherbiny, 2011; Manju and Subramanians, 2015). They are commonly associated with rhizospheres of many species of plants. Plantparasitic nematodes have caused severe damages on plants where they attack the plants and alter the whole functioning of the plants. The symptoms observe varies with tree species and these symptoms include loss of vigour, small and distorted root systems, root galls and decay of feeder roots and sometimes death (Khan, 2012). One difficulty in assessing nematode impact is that damage resulting from nematode infection is often less obvious than that caused by many other pests or diseases. Losses that result from nematode attack may not necessarily be as a consequence of direct cell death, necrosis or 'diseased' tissue. However, they may be derived from other more insidious aspects, such as interference with the root system, reducing their efficiency in terms of access and uptake of nutrients and water. To the unaware, nematode-affected plants present typical drought and nutrient stress symptoms, which are easily and often misdiagnosed (Nicol et al., 2011). Detection of pathogens such as nematodes is often difficult because, pathogens often have lag times of several years between infection and the trees developing external or visible symptoms (Brasier, 2008). As a result of this, nematode identification and population determination is important for the healthy growth of trees. The identification of new or potentially harmful species of nematodes is important to their effective management (Zafar, 1998). This study was to identify and determine the abundance of plant-parasitic nematodes associated with amenity trees in University of Port Harcourt, Rivers State, Nigeria

\section{MATERIALS AND METHODS}

Research Site: The survey for plant-parasitic nematodes of amenity trees was carried out within the three parks (Choba, Delta and University) of the University of Port Harcourt (UNIPORT), Rivers State, Nigeria. The survey was carried out in July to August 2019. University of Port Harcourt is located at coordinates $4^{\circ} 52^{\prime} 30^{\prime \prime}$ and $4^{\circ} 55^{\prime} 40^{\prime \prime} \mathrm{N}, 6^{\circ} 54^{\prime} 40^{\prime}$ 'and $6^{\circ} 55^{\prime} 49^{\prime \prime}$ E with an elevation of $18 \mathrm{~m}$ above sea level, temperature of $28-33^{\circ} \mathrm{C}$ and with rainfall ranging from 2000-2680 mm per annum (Eludoyin et al., 2015). The sampling location cut across all the major roads, pathways and buildings in the university.

Research Design and Reconnaissance of Amenity Trees: Identification of amenity trees and their population in UNIPORT was carried out in a reconnaissance survey under the supervision of a plant taxonomist in June, 2019. The three parks of UNIPORT were surveyed using random sampling design method for the collection of roots and soil samples of amenity trees (Adesoye, 2011). Coordinates of locations where trees were found were taken using E-trex Garmin Geo Positioning System (GPS).

Collection of Soil and Root Samples: Twenty-one (21) tree species were selected base on their relative importance values for collection of soil and root samples from the outcome of the reconnaissance survey. The trees were randomly selected and samples were collected from five stands of each tree species. Soil and root samples were collected from both the soil and roots of the selected amenity trees to facilitate the extraction and identification of plant-parasitic nematodes present using standard procedures. Soil of $500 \mathrm{~cm}^{3}$ were collected from the rhizospheres of each tree using hand trowel to a depth of $30 \mathrm{~cm}$ and bagged into a well labelled polythene bag. The roots were also collected from the same tree species using knife and added to the polythene bag. The bulked soil samples were taken to the laboratory for extraction. Soil and root samples were collected from all the selected 21 amenity trees. A total of 126 composite root and soil samples were collected across the University.

Extraction Procedure for Plant-parasitic Nematodes: The extraction of the plant-parasitic nematodes from the soil samples was done using the extraction tray method (Whitehead and Hemming, 1965; Coyne et al., 2007) at the Crop Protection Laboratory, Department of Crop and Soil Science, University of Port Harcourt. Each bulked soil sample was placed in a dish and sieved to remove debris from it and then it was evenly mixed. $200 \mathrm{~cm}^{3}$ soil sample was poured on a facial tissue in a plastic sieve on an extraction tray and water was added by the side. The extraction set-up was allowed for 48 hours after which the sieve was removed and the water was poured into a beaker. The suspension was kept for a day and allowed to settle. The suspension was later decanted and the suspension containing nematodes were poured into a sample bottle and preserved in the refrigerator prior to identification and counting. The bottles containing nematode suspension were later sent to the Nematology Research 
Laboratory, International Institutes for Tropical Agriculture (IITA), Ibadan, Oyo State for identification and counting.

The extraction of the plant-parasitic nematodes from the roots samples was done with the extraction tray method (Whitehead Hemming, 1965; Coyne et al., 2007). Roots collected from each sample were properly rinsed with water to get rid of debris. The roots were chopped into small parts of 1-2 cm and from each bulked sample, 10 grams of the chopped roots of each sample was weighed out using an electronic weighing scale. The chopped roots were poured on the facial tissue inside the sieve and water was added by the side. The extraction set-up was allowed for 48 hours after which the sieve was removed and the water was poured into a beaker.

The suspension was allowed to settle for one to two hours, after which it was decanted and the suspension containing the nematodes was poured into a sample bottle and preserved in the refrigerator prior to identification and counting. Identification and population count of plant-parasitic nematodes were done at IITA Nematology Research Laboratory, Ibadan, Oyo State, Nigeria. Eppendorf pipette was used to take one millilitre of nematode suspension from $10 \mathrm{ml}$ sample bottle and this was subsequently released into a counting slide.

The counting slide was placed under a Wild Leitz GMBH compound microscope and identification keys of Mai et al., (1996), Mekete et al., (2012) and Nematode Diagnostic Compendium at the IITA Nematology Research Laboratory were used to identify nematode pests to genera level. The identified nematodes were counted with the aid of a multiple tally counter. Each count for each nematode species was extrapolated to the volume of the sample bottle to determine the population count.

Data Processing and Analyses: Descriptive statistics were used to process data on frequency of occurrence of amenity trees and nematodes with these formulas (Norton, 1978);

$$
\begin{gathered}
A F O=\frac{\text { No of occurence of species }}{\text { Number of samples collected }} \\
\text { RFO }=\frac{\text { Frequency of a species }}{\text { Frequency of all species }}
\end{gathered}
$$

Nematode Abundance and Relative Importance Value: Nematode abundance and relative importance value of plant-parasitic nematode species were determined using the methods of Kent and Coker (1996) and Shukla and Chandel (2014) with modifications.

$$
\begin{gathered}
A B=\frac{T_{i}}{T_{S}} \\
R D=\frac{\text { Density of individual species }}{\text { Total density of all species }} \times \frac{100}{1} \\
R I V(\%)=\frac{R D+R F}{2}
\end{gathered}
$$

Where $\mathrm{AFO}=$ absolute frequency of occurrence; RFO $=$ relative frequency of occurrence; $\mathrm{AB}=$ Abundance, $\mathrm{Ti}=$ total number of individual species in all samples, Ts $=$ total number of samples in which the species occurred; $\mathrm{RD}=$ relative density, $\mathrm{RF}=$ relative frequency, $\mathrm{RIV}=$ relative importance value

Determination of Community Structure and Diversity of Nematode Communities: The Paleontological Statistical Tool (PAST) of Hammer et al. (2001) was used to determine the diversity of nematode communities. Some indices calculated were:

(a) Genera (G) or Species Richness (S): This is the simple count of different species per organism.

(b) Shannon - Wiener index $\left(\mathrm{H}^{\prime}\right):\left(\mathrm{H}^{\prime}\right)=$

$-\sum$ (pi) (Inpi)

(c) Evenness index (J) =

$\frac{\mathrm{H}^{\prime}}{\mathrm{InS}}$; Where, $\mathrm{S}$ Number of species enumerated in the community.

(d) Dominance index $=\sum(\mathrm{ni} / \mathrm{n})^{2}$

Data from nematode counts were transformed using $\log 10(\mathrm{x}+1)$, then analyzed with analysis of variance (ANOVA) and means were separated using Fisher's Least Significant Difference at probability of 5\% with Statistical Analysis System (SAS, 2007) package.

\section{RESULTS AND DISCUSSION}

Relative Importance Values of Amenity Tree Species in the University of Port Harcourt: Thirty-eight (38) amenity tree species were identified belonging to 20 families from the reconnaissance survey (Table 1). The major families of trees encountered were Moraceae, Fabaceae, and Arecaceae.

The five most important tree species in UNIPORT were Terminalia mantaly, Cocos nucifera, Terminalia catappa Azadirachta indica and Polyathia longifolia with the relative importance values (RIV) of $15.1 \%$, $9.35 \%, 9.12 \%, 8.18 \%$, and $4.57 \%$, respectively. The least prominent amenity trees encountered in UNIPORT were Ficus exasperata and Syziguim malaccense with the same RIV of $0.42 \%$ (Table 1 ). 
Table 1: Occurrence and relative importance values of amenity tree species in the University of Port Harcourt

\begin{tabular}{lllll}
\hline Tree Species & Family & $\begin{array}{l}\text { Frequency of } \\
\text { occurrence }\end{array}$ & $\begin{array}{l}\text { Relative frequency } \\
\text { of occurrence (\%) }\end{array}$ & RIV (\%) \\
\hline Delonix regia & Fabaceae & 7 & 5.22 & 4.23 \\
Peltophorum pterocarpum & Fabaceae & 5 & 3.73 & 3.18 \\
Hura crepitans & Euphorbiaceae & 5 & 3.73 & 2.88 \\
Persia Americana & Lauraceae & 1 & 0.75 & 0.53 \\
Polyathia longifolia & Annonaceae & 6 & 4.48 & 4.57 \\
Gmelina arborea & Lamiaceae & 3 & 2.24 & 1.68 \\
Terminalia mantaly & Combretaceae & 11 & 8.21 & 15.1 \\
Azadiracha indica & Meliaceae & 4 & 2.99 & 8.18 \\
Terminalia catappa & Combretaceae & 14 & 10.45 & 9.12 \\
Ficus exasperate & Moraceae & 1 & 0.75 & 0.42 \\
Ficus benjamina & Moraceae & 3 & 2.24 & 1.73 \\
Ficus elastic & Moraceae & 3 & 2.24 & 1.47 \\
Syzigium malaccense & Myrtaceae & 1 & 0.75 & 0.42 \\
Arenga pinnata & Palmae & 3 & 2.24 & 2.84 \\
Roystonea regia & Arecaceae & 2 & 1.49 & 1.51 \\
Syagrus romanzoffiana & Arecaceae & 2 & 1.49 & 0.90 \\
Casuarina equisetifolia & Casuarinaceae & 1 & 0.75 & 0.47 \\
Pterocarpus santalinoides & Fabaceae & 2 & 1.49 & 0.80 \\
Cocos nucifera & Palmae & 7 & 5.22 & 9.35 \\
Mangifera indica & Anacardiaceae & 6 & 4.48 & 3.91 \\
Tectona grandis & Lamiaceae & 2 & 1.49 & 0.80 \\
Lagerstroemia indica & Lythraceae & 3 & 2.24 & 1.68 \\
Anacardium occidentalis & Anacardiaceae & 2 & 1.49 & 1.10 \\
Dacryodes edulis & Burseraceae & 2 & 1.49 & 0.90 \\
Elaeis guineensis & Arecaceae & 2 & 1.49 & 4.09 \\
\hline
\end{tabular}

RIV $=$ Relative importance value

Table 1 Cont'd.: Occurrence and relative importance values of amenity tree species in the University of Port Harcourt

\begin{tabular}{|c|c|c|c|c|}
\hline Tree species & Family & $\begin{array}{l}\text { Frequency of } \\
\text { occurrence }\end{array}$ & $\begin{array}{l}\text { Relative frequency of } \\
\text { occurrence }(\%)\end{array}$ & RIV (\%) \\
\hline Ambodia gadis & & 2 & 1.49 & 0.80 \\
\hline Alstonia boonei & Apocynaceae & 2 & 1.49 & 0.85 \\
\hline Musanga cecropioides & Urticaceae & 2 & 1.49 & 0.80 \\
\hline Milicia excels & Moraceae & 2 & 1.49 & 0.90 \\
\hline Treculia Africana & Moraceae & 2 & 1.49 & 0.80 \\
\hline Spondias cytherea & Anacardiaceae & 1 & 0.75 & 0.47 \\
\hline Chrysophyllum albidum & Sapotaceae & 4 & 2.99 & 1.95 \\
\hline Terminalia ivorensis & Combretaceae & 2 & 1.49 & 0.80 \\
\hline Senna fistula & Fabaceae & 3 & 2.24 & 1.63 \\
\hline Pinus caribaea & Pinaceae & 6 & 4.48 & 4.21 \\
\hline Eucalyptus camadulensis & Myrtaceae & 4 & 2.99 & 2.10 \\
\hline Samanea saman & Fabaceae & 2 & 1.49 & 0.80 \\
\hline Citrus sinensis & Rutaceae & 4 & 2.99 & 2.05 \\
\hline Total & & 134 & 100.0 & 100.0 \\
\hline
\end{tabular}

Diversity of Amenity Tree Species in the University of Port Harcourt: The results for diversity of amenity trees species in UNIPORT is presented in Figure 1. The diversity indices such as Dominance, Shannon Wiener and Evenness were calculated. Dominance value for amenity tree species for taxa of 38 tree species is 8.51 , Shannon Wiener index was 2.69 and the value for Evenness was 0.39.

Relative importance values of plant-parasitic and diversity of plant-parasitic nematodes associated with soil of amenity trees at the University of Port Harcourt: Helicotylenchus multicinctus with the RIV of $45.41 \%$ was the most important nematode pest genus associated with the soil of the amenity trees (Table 2). This was followed by Tylenchulus spp. with
RIV of $14.67 \%$. The least important nematode pest genera were Trichodorus spp, Mesodorylaimus spp. and Paratylenchus spp, all having the same RIV of $1.37 \%$. Figure 2 shows results for the diversity of plant-parasitic nematodes associated with the soil of amenity trees. Fifteen nematode pest genera were encountered in the soil. The Dominance index for the nematode pests was 0.33 , Shannon Wiener index of 1.73 and Evenness value of 0.38 .

Relative importance values and diversity indices of plant-parasitic nematodes found in the roots of amenity trees at the University of Port Harcourt: Tylenchulus spp. had the highest RIV of 30\%, then Helicotylenchus multicinctus with RIV of $18.33 \%$, followed by Aporcelaimus species (RIV 12.22\%) 
(Table 3). The least prominent nematode pests were Rotylenchoides spp., Criconema spp., Hemicyliophora spp., Trichodorus spp. and Longidorus spp. with equal RIV of $6.11 \%$.Figure 3 shows results for the diversity of nematode pests associated with roots of amenity trees. Dominance value for nematode pests was 0.22 , Shannon Wiener of 1.80 and the value for Evenness was 0.76 .

Mean relative importance values and diversity indices of plant-parasitic nematodes associated with amenity trees at University of Port Harcourt: Table 4 shows the results for occurrence and relative importance values of plant-parasitic nematodes found in roots of amenity trees. Helicotylenchus multicinctus had the highest RIV of $42 \%$ and Tylenchulus spp. with the RIV of $16 \%$. Mean diversity indices of plant-parasitic nematodes associated with amenity tree species at the University of Port Harcourt is presented in Figure 4. The average Dominance index for nematode pests of amenity trees in UNIPORT was 0.29 , whereas the Shannon Wiener index was 1.83 and the Evenness index was 0.41 .

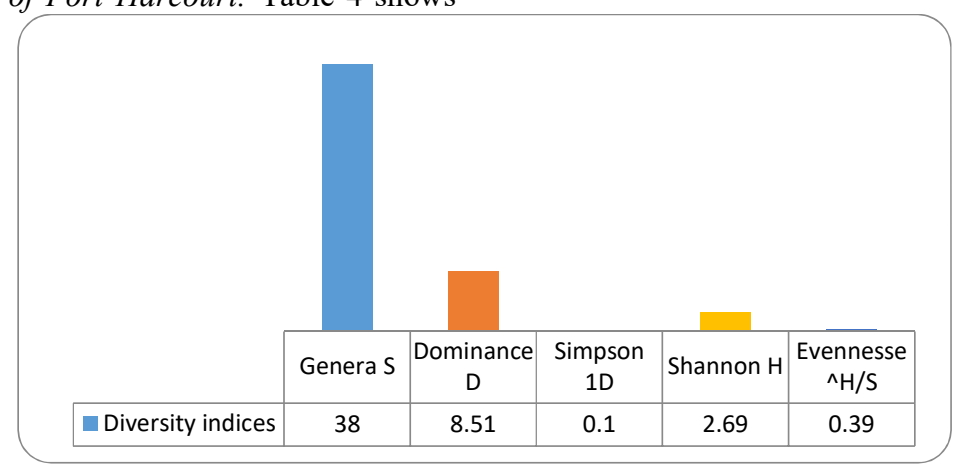

Fig 1: Diversity indices of amenity tree Species in the University of Port Harcourt

Table 2: Relative importance values of plant-parasitic nematodes found in the soil of amenity trees at the University of Port Harcourt

\begin{tabular}{llll}
\hline Plant-parasitic Nematodes & Frequency & Relative frequency (\%) & *RIV (\%) \\
\hline Helicotylenchus spp. & 18 & 36 & 45.41 \\
Aporcelaimus spp. & 3 & 6 & 4.48 \\
Tylenchulus spp. & 8 & 16 & 14.67 \\
Meloidogyne spp. & 3 & 6 & 5.22 \\
Scutelonema spp. & 2 & 4 & 3.85 \\
Pratylenchus spp. & 1 & 2 & 1.74 \\
Tylenchus spp. & 2 & 4 & 3.11 \\
Rotylenchoides spp. & 2 & 4 & 3.11 \\
Criconema spp. & 3 & 6 & 5.22 \\
Hemicyliophora spp. & 2 & 4 & 4.22 \\
Trichodorus spp. & 1 & 2 & 1.37 \\
Mesodorylaimus spp. & 1 & 2 & 1.37 \\
Heterodera spp. & 1 & 2 & 2.11 \\
Paratylenchus spp. & 1 & 2 & 1.37 \\
Longidorus spp. & 2 & 4 & 2.74 \\
Total & $\mathbf{5 0}$ & $\mathbf{1 0 0}$ & $\mathbf{1 0 0}$ \\
\hline & RIV Relative Importance Value
\end{tabular}

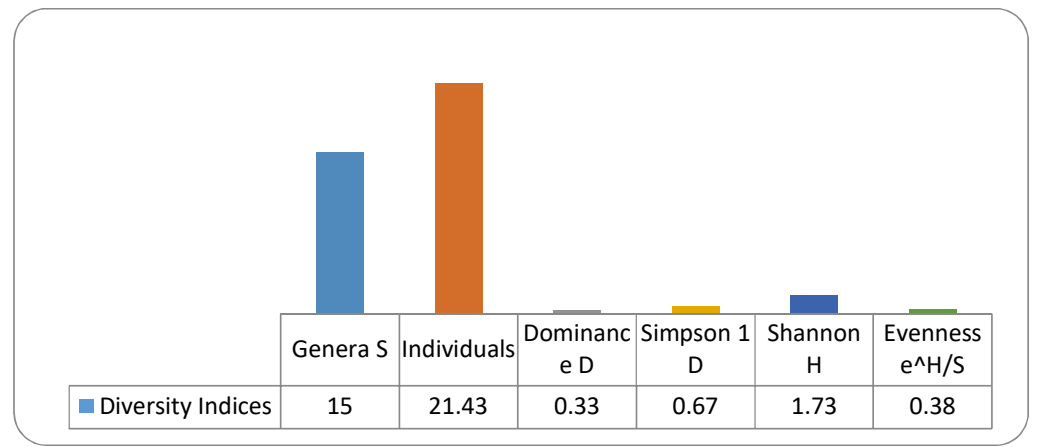

Fig 2: Diversity indices of plant-parasitic nematodes associated with soil of amenity tree species at the University of Port Harcourt 
Table 3: Occurrence and relative importance values of plant-parasitic nematodes found in the roots of amenity trees at the University of Port Harcourt

\begin{tabular}{llll}
\hline Plant-Parasitic Nematode Genera & Frequency & Relative frequency (\%) & ${ }^{*}$ RIV (\%) \\
\hline Helicotylenchus spp. & 3 & 20 & 18.33 \\
Aporcelaimus spp. & 2 & 13.33 & 12.22 \\
Tylenchulus spp. & 4 & 26.67 & 30 \\
Pratylenchus spp. & 1 & 6.67 & 8.89 \\
Rotylenchoides spp. & 1 & 6.67 & 6.11 \\
Criconema spp. & 1 & 6.67 & 6.11 \\
Hemicyliophora spp. & 1 & 6.67 & 6.11 \\
Trichodorus spp. & 1 & 6.67 & 6.11 \\
Longidorus spp. & 1 & 6.67 & 6.11 \\
Total & 15 & 100 & 100 \\
\hline \multicolumn{2}{c}{}
\end{tabular}

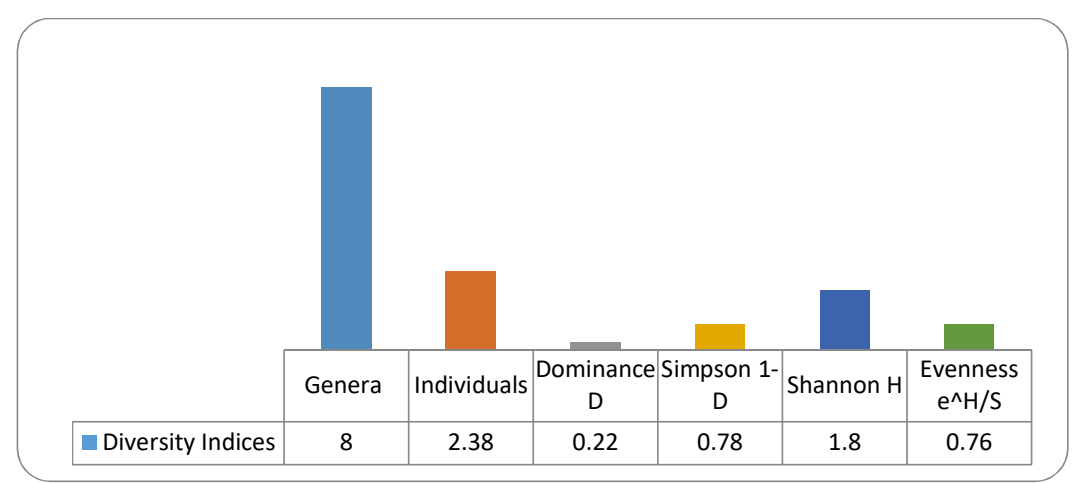

Fig 3: Diversity indices of plant-parasitic nematodes associated with roots of amenity tree species at the University of Port Harcourt

Mean population of plant-parasitic nematodes associated with amenity trees in the University of Port Harcourt: Terminalia catappa had the highest mean population of Helicotylenchus species, Arenga pinnata had the highest mean of population of Aporcelaimus, whereas the highest population of Tylenchulus was found on Terminalia catappa (Table 5). The highest population of Meloidogyne was found on Anacardium occidentalis, Roystonea regia had the highest population of Scutellonema, Polyathia longifolia and Persia americana were the only amenity trees with the same population of Pratylenchus.

The highest mean populations of Tylenchus, Rotylenchus, Criconemella, Hemiclyclophora, Trichodorus, Mesodorylaimus, Heterodera, Paratylenchus and Longidorus were found in Cocos nucifera, Mangifera indica, Anacardium occidentalis, Terminalia mantaly, Ficus elastica, Delonix regia, Delonix regia, Hura crepitans and Elaeis guineensis, respectively (Table 5). The highest mean population of plant-parasitic nematodes of 106.67 was obtained from Terminalia catappa, but was not significantly higher than mean population of nematode pests of other amenity trees in UNIPORT (Table 5). The tree species identified in UNIPORT as amenity trees are 38 and classified into twenty families viz; Fabaceae, Euphorbiaceae, Lauraceae, Annonanceae,
Combretaceae, Meliaceae, Moraceae, Myrtaceae, Palmae, Arecaceae, Casuarinaceae, Anacardiaceae, Lambiaceae, Lythraceae, Burseraceae, Apocynaceae, Urticaceae, Sapotaceae, Rutaceae and Pinaceae. Most of the trees belong to the Moraceae family. These prominent trees encountered in this study were in conformity with the reports of other workers as being effective as amenity trees (Babalola and Raji, 2016; Ugbaja, 2018). The cultivation of these encountered trees in UNIPORT could be due to their ability to provide shade, fruits, aesthetic values, increase property values (Hedonic) and their ease of growth (Schroeder, 1989; Panduro and Veie, 2013; Rosato et al., 2017).

Plant-parasitic nematodes found associated with amenity trees across UNIPORT varied in population densities and they are of different genera. The nematodes found affecting amenity trees in UNIPORT are of 15 genera; Helicotylenchus spp, Aporcelaimus spp. Meloidogyne spp., Scutelonema spp., Pratylenchus spp., Tylenchus spp., Rotylenchoides spp., Criconema spp., Hemicyliophora spp., Trichodorus spp., Mesodorylaimus spp., Heterodera spp., Paratylenchus spp., Longidorus spp. and Tylenchulus spp. However, the three major genera are: Helicotylenchus spp., Aporcelaimus spp. and Tylenchulus spp. 
Table 4: Relative importance values of plant-parasitic nematodes associate with amenity trees at the University of Port Harcourt

\begin{tabular}{llll}
\hline $\begin{array}{l}\text { Plant-parasitic } \\
\text { Nematodes Genera }\end{array}$ & $\begin{array}{l}\text { Frequency of } \\
\text { Occurrence }\end{array}$ & $\begin{array}{l}\text { Relative frequency } \\
\text { of Occurrence (\%) }\end{array}$ & $\begin{array}{l}\text { RIV } \\
\text { (\%) }\end{array}$ \\
\hline Helicotylenchus spp. & 20 & 33.33 & 42 \\
Aporcelaimus spp. & 4 & 6.67 & 5.34 \\
Tylenchulus spp. & 10 & 16.67 & 16 \\
Meloidogyne spp. & 3 & 5 & 4.5 \\
Scutelonema spp & 2 & 3.33 & 3.34 \\
Pratylenchus spp. & 2 & 3.33 & 3 \\
Tylenchus spp. & 2 & 3.33 & 2.67 \\
Rotylenchoides spp. & 3 & 5 & 3.83 \\
Criconema spp. & 3 & 5 & 4.5 \\
Hemicyliophora spp. & 3 & 5 & 4.83 \\
Trichodorus spp. & 2 & 3.33 & 2.33 \\
Mesodorylaimus spp. & 1 & 1.67 & 1.17 \\
Heterodera spp. & 1 & 1.67 & 1.83 \\
Paratylenchus spp. & 1 & 1.67 & 1.17 \\
Longidorus spp. & 3 & 5 & 3.5 \\
Total & 60 & 100 & 100 \\
\hline
\end{tabular}

$* R I V=$ Relative Importance Value

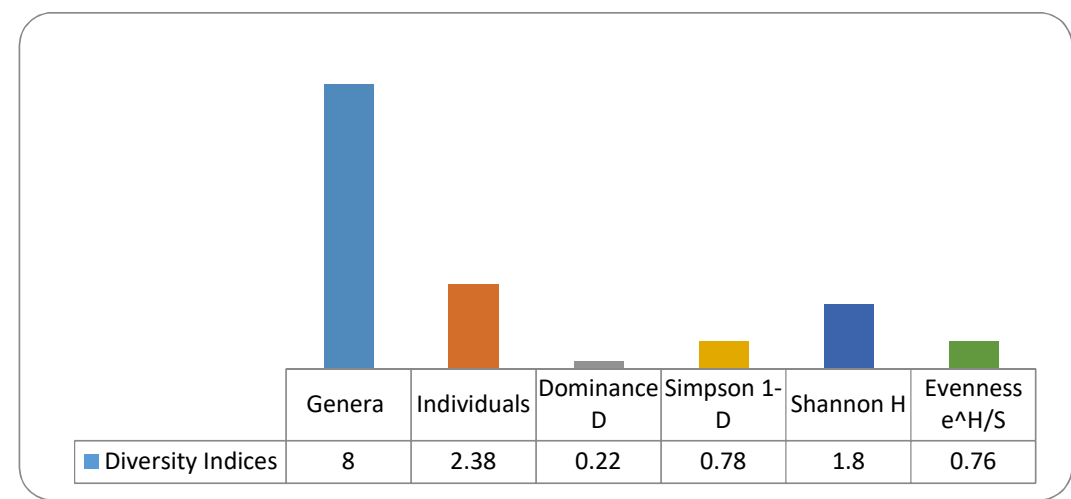

Fig 4: Diversity indices of plant-parasitic nematodes associated with Amenity tree species at UNIPORT

These nematodes found on amenity trees are in conformity with nematode pests that have been reported on trees due to their wide host range and mode of feeding (Ruehle, 1967; Ruehle, 1973; Gbadegesin et al., 1992; Gbadegesin et al., 1993; Nyczepir and Becker, 1998). The economically most important nematode pest species belong to the genera Criconemella, Meloidogyne, Pratylenchus, Longidorus, Xiphinema, Trichodorus and Paratrichodorus, and are widely distributed on tree crops throughout the world (Nyczepir and Halbrendt, 1993; Nyczepir and Becker, 1998). The traditional nematode genera associated with trees globally such as Trichodorus, Paratrichodorus, Longidorus, Xiphinema were found in significant abundance in this survey (Nyczepir and Becker, 1998; Lišková et al., 2007). These nematodes have been implicated in damage to forest trees with slow decline of growth and eventual tree death in 5 to 10 years, especially in young forest plantations (Khan, 2012). Wilting, drying, defoliation of branch or entire tree has been attributed to attack of nematode pests on trees (Khan, 2012). This shows the importance of plant-parasitic nematodes as one of the major constraints to growth of amenity trees. Also, Aporcelaimus species of the family Aporcelaimidae and Mesodorylaimus species (Dorylaimidae) classified as omnivores and predators (Andrassy, 2000; McSorley, 2012) are just being reported first in the rhizospheres of trees in Nigeria. The presence of these two nematode species has been linked to ecosystems in nearly all stages of succession, but they have their highest population at the later stages of succession especially in soils of old-growth forests (McSorley, 2012). They have strong adaptation to extreme environment, but are limited by soil with low $\mathrm{PH}$, use of inorganic fertilizers and other agrochemicals. The report of these two nematode pest genera is an indication that their host range have increased either due to climate change or favourable environmental conditions. Recently, change in pest status has been linked to climate change in which potential pests of some plants are now becoming key pests (Asimiea et al., 2015). 
Table 5: Mean population of plant-parasitic nematodes associated with amenity trees at the University of Port Harcourt

\begin{tabular}{|c|c|c|c|c|c|c|c|c|c|c|c|c|c|c|c|c|}
\hline Tree Species & Heli & Apo & Tyle & Melo & Scut & Praty & Tylchus & Roty & Crico & Hemi & Trich & Meso & Hetero & Parat & Longi & Mean PPNs \\
\hline Delonix regia & 0 & 0 & 0 & 0 & 0 & 0 & 3.33 & 0 & 0 & 0 & 0 & 3.33 & 10 & 0 & 0 & $16.66(0.57)$ \\
\hline Peltphorum pterocarpum & 23.33 & 10 & 0 & 0 & 0 & 0 & 0 & 0 & 0 & 0 & 0 & 0 & 0 & 0 & 0 & $33.3(1.23)$ \\
\hline Hura crepitans & 10 & 0 & 0 & 0 & 0 & 0 & 0 & 3.33 & 0 & 0 & 0 & 0 & 0 & 3.33 & 0 & $16.66(1.23)$ \\
\hline Polyathia longifolia & 0 & 0 & 0 & 0 & 0 & 6.67 & 0 & 0 & 0 & 3.33 & 0 & 0 & 0 & 0 & 0 & $10.00(0.79)$ \\
\hline Persia americana & 0 & 0 & 0 & 0 & 0 & 6.67 & 0 & 0 & 0 & 0 & 0 & 0 & 0 & 0 & 0 & $16.67(0.88)$ \\
\hline Gmelina arborea & 0 & 0 & 0 & 0 & 0 & 0 & 0 & 0 & 3.33 & 0 & 0 & 0 & 0 & 0 & 0 & $3.33(0.35)$ \\
\hline Terminalia mantaly & 0 & 0 & 0 & 0 & 0 & 0 & 0 & 0 & 0 & 0 & 3.33 & 0 & 0 & 0 & 0 & $0.00(0)$ \\
\hline Azadiracha indica & 10 & 0 & 3.33 & 0 & 0 & 0 & 0 & 0 & 0 & 0 & 0 & 0 & 0 & 0 & 0 & $13.33(0.88)$ \\
\hline Terminalia catappa & 76.67 & 0 & 26.67 & 0 & 0 & 0 & 0 & 0 & 0 & 0 & 0 & 0 & 0 & 0 & 0 & $106.67(1.27)$ \\
\hline Ficus elastica & 6.67 & 0 & 0 & 0 & 0 & 0 & 0 & 0 & 0 & 3.33 & 3.33 & 0 & 0 & 0 & 0 & $13.33(0.84)$ \\
\hline Arenga pinnata & 36.67 & 6.67 & 13.33 & 6.67 & 0 & 0 & 0 & 0 & 0 & 0 & 0 & 0 & 0 & 0 & 0 & $63.33(1.31)$ \\
\hline Roystonea regia & 10 & 0 & 6.67 & 0 & 10 & 0 & 0 & 0 & 0 & 0 & 0 & 0 & 0 & 0 & 0 & $26.67(0.64)$ \\
\hline Cocos nucifera & 0 & 3.33 & 0 & 0 & 0 & 0 & 6.67 & 0 & 0 & 0 & 0 & 0 & 0 & 0 & 0 & $10.00(0.79)$ \\
\hline Mangifera indica & 3.33 & 0 & 0 & 0 & 0 & 0 & 0 & 10 & 0 & 0 & 0 & 0 & 0 & 0 & 0 & $3.33(0.35)$ \\
\hline Lagerstroemia indica & 3.33 & 0 & 3.33 & 0 & 0 & 0 & 0 & 0 & 0 & 0 & 0 & 0 & 0 & 0 & 0 & $6.67(0.69)$ \\
\hline Anacardium occidentalis & 16.67 & 0 & 0 & 10 & 6.67 & 0 & 0 & 0 & 13.33 & 16.67 & 0 & 0 & 0 & 0 & 0 & $63.33(1.31)$ \\
\hline Elaeis guinensis & 50 & 0 & 6.67 & 3.33 & 0 & 0 & 0 & 0 & 3.33 & 0 & 0 & 0 & 0 & 0 & 6.67 & $70.00(1.84)$ \\
\hline Chrysophyllum albidum & 0 & 0 & 3.33 & 0 & 0 & 0 & 0 & 0 & 0 & 0 & 0 & 0 & 0 & 0 & 0 & $3.33(0.35)$ \\
\hline Senna fistula & 0 & 0 & 3.33 & 0 & 0 & 0 & 0 & 0 & 0 & 0 & 0 & 0 & 0 & 0 & 0 & $3.33(0.35)$ \\
\hline Pinus caribaea & 3.33 & 0 & 10 & 0 & 0 & 0 & 0 & 0 & 0 & 0 & 0 & 0 & 0 & 0 & 0 & $13.33(0.54)$ \\
\hline Eucalyptus camadulensis & 3.33 & 0 & 0 & 0 & 0 & 0 & 0 & 0 & 0 & 0 & 0 & 0 & 0 & 0 & 3.33 & $6.67(0.44)$ \\
\hline LSD $(\mathrm{P} \leq 0.05)$ & 52.85 & 7.77 & 16.74 & 7.76 & 7.49 & 5.87 & 4.64 & 4.15 & 8.81 & 10.79 & 2.94 & 2.08 & 6.23 & 2.08 & 2.93 & $74.71(1.33)$ \\
\hline
\end{tabular}

Heli=Helicotylenchus; $\mathrm{Apo}=$ Apocelaimus; Tyle=Tylenchulus; Melo=Meloidogyne; Scut=Scutellonema $;$ Praty=Pratylenchus; Tylchus=Tylenchus; Roty=Rotylenchulus; Crico=Criconemella $;$ Hemi=Hemicyclophora

Tric $=$ Trichodorus; Meso=Mesodorylaimus; Hetero= Heterodera; Parat=Paratylenchus; Longi=Longidorus; PPNs=Plant-parasitic nematodes; ()$=\operatorname{logarithm}$ transformed value

Conclusion: Thirty-eight (38) amenity tree species belonging to 20 families were identified in UNIPORT, one of which Moraceae constitutes the major family. The nematode pests of amenity trees in UNIPORT belong to 15 genera, with three predominant genera are Helicotylenchus, Tylenchulus and Aporcelaimus. Further research should be carried out on the effects of these nematodes on the amenity trees and how they could be well managed sustainably.

\section{REFERENCES}

Adesoye, PO (2011). Introduction to design and analysis of questionnaire, Debo prints, Ibadan. $128 \mathrm{p}$. Nigeria

Agbelade, AD; Onyekwelu, JC; Apogbona, O (2016). Assessment of urban forest tree species population and diversity in Ibadan, Nigeria. Envr. Eco. Res., 4(4): 185 192

Aldous, DE (2007). Social, environmental, economic, and health benefits of green spaces. In: Lumpkin, TA, Wrrignton, IJ (eds) proceedings of the international symposium on Horticultural Plants in Urban and Peri-Urban Life, Acts Horticulture, 762, International Society of Horticultural Science, Leuven 1, pp $171-185$

Andrassy, I (2000). Four large-sized species of the family Aporcelaimidae (Nematoda, Dorylaimida) with proposal of a new genus, Epacrolaimus gen. n. Opuscula Zoo. Bud 32:3-26

Asimiea, AO; Tanimola, AA; Bob-Manuel, BP (2015). Nematode pests of cassava (Manihot esculenta Crantz) in three Local Government Areas of Rivers State in Nigeria. J. of Appl. Sci. Agric: 10 (6): 68-77

Babalola, FD; Raji, IA (2016). Perception of urban trees at main campus of University of Ilorin, Ilorin Kwara State, Nigeria. Appl. Trop. Agric 21 (1): $60-67$

Brasier, CM (2008). The biosecurity threat to the UK and global environment from international trade in plants. Plt. Path. 57:792-808

OSENI, L; TANIMOLA, AA; WOKOMA, EC; OLADELE, AT 
Coyne, DL; Nicol, JM; Claudius-Cole, B (2007). Plant parasitic nematology: a field and laboratory guide. SP. IPM secretariat, International Institute of Tropical Agriculture (IITA), Cotonou, Benin Cullen, S (2007). Putting a value on trees - CTLA guidance and methods. Arbo. J., 30: $21-43$

Dvorak, WS (2004). World view of Gmelina arborea: opportunities and challenges 28: (Issue 2-3):111 $-126$

Dwyer, JF; Nowak, DJ; Noble, MH; Sisinni, SM (2000). Connecting people with ecosystems in the $21^{\text {st }}$ century, an assessment of Our Nation's Urban forests. Gen. Tech. rep. PNW-GTR-490. Portland, or: USDA Forest Service, Pacific Northwest Research Station. 483 p

El-Sherbiny, AA (2011). Phytoparasitic nematodes associated with ornamental shrubs, trees, and palms in Saudi Arabia, including new host records, nematology research department, Plant Pathology Research Institute, Agriculture Research Centre, Giza Egypt. Pak. J. Nematol. 29:147-164

Eludoyin, OS; Oladele, AT; Iyanda, OM (2015). Mapping and assessment of ethno-medicinal trees in built up areas - University of Port Harcourt, Nigeria. S-E. Euro. For., 6 (1): 129-140

Fuwape, JA; Onyekwelu, JC (2011). Urban forest development in West Africa: benefits and challenges. J. Biod. Eco. Sci., 1(1):77 - 94

Gbadegesin, RA; Adesiyan, SO; Khan, FA (1992). Plant-parasitic nematodes associated with Pinus species in the savanna areas of Nigeria. National Agricultural Extension and Research Liaison services. J. Afr. Zoo. 106(6):463-470

Gbadegesin, RA; Adesiyan, SO; Khan, FA (1993). Effects of seasonal changes on the population levels of some plant-parasitic nematodes in the plantations of Pinus caribaea and P. oocarpa in the savanna areas of Nigeria. For. Ecol. Man. 60: 345-53.

Gunderson, P; Schmidt, IK; Rasmussen, KR (2006). Leaching of nitrate from temperate forests effects on air pollution and forest management. Environ. Revs. 14 (1): 1-57

Hagan, A (2005). Nematode pests of annual and perennial flowers, herbs, woody shrubs, and trees. Alabama Cooperatives Extension System, ANR689
Haysom, K; Murphy, ST (2003). The status of invasiveness of forest tree species outside their natural habitat: a global review and discussion paper. Forest Health and Biosecurity Working Paper FBS/3E. Forestry Department, FAO, Rome $2003 . \quad$ Available http://www.fao.org/docrep/006/ $\mathrm{j} 1583 \mathrm{e} / \mathrm{j} 1583 \mathrm{e} 00 . \mathrm{htm}$ (accessed 08.02.2019).

Hall, CM; James, M; Baird, T (2011). Forests and trees as charismatic mega-flora: implications for heritage tourism and conservation. J. Heri. Tour. 6: 309-323

Hammer, O; Harper, DAT; Ryan, PD (2001). PAST: Paleotological statistic software package for education and data analysis. Paleontol. Electro. 4(1): 9

James, AL; Andrew, JL; Mark, E; Swanson, E; James, AF (2012). Ecological importance of largediameter trees in a temperate mixed conifer forests. Published: May 2012 https://doi.org/10.1371/journal.pone.0036131

Jim, CY; Chen, WY (2009). Diversity and distribution of landscape trees in the compact Asian city of Taipei. Appl. Geo. 29(4): 577-587

Kent, M; Coker, P (1996). Vegetation description and analysis. A practical approach. John Wiley and Sons, NY, pp 363

Khan, MR (2012). Nematodes, an emerging threat to global forests: Assessment and management. Plt. Path. J. 11(4):99-113

Lišková, M; Sasanelli, N; D’Addabbo, T (2007). Some notes on the occurrence of plant parasitic nematodes on fruit trees in Slovakia. Plt. Prot. Sci., 43: 26-32.

Mai, WF; Mullin, PG; Lyon, HH; Loeffler, K (1996). Plant-parasitic nematodes: A pictorial key to genera. The Quart. Rev. Biol., 71 (4): 584

Manju, P; Subramanian, S (2015). Survey of plant parasitic nematodes associated with Gerbera in Tamil Nadu. Inter. J. Sci. Nat. 6(4): 586-589

McSorley, R (2012). Ecology of the dorylaimid omnivore genera Aporcelaimellus, Eudorylaimus and Mesodorylaimus. Nematol. 14:645-663.

Mekete, T; Dababat, A; Sekora, N; Akyazi, F; Abebe, E (comps). (2012). Identification key for 
agriculturally important plant-parasitic nematodes. Prepared for the International Nematode Diagnosis and Identification Course 2012 -A manual for nematology. Mexico, D.F.: CIMMYT xiv +40

Nicol, JM; Turner, SJ; Coyne, DL; Nijs, D; Hockland, S; Tahna, MZ (2011). Current nematode threats to world agriculture. J. Jones et al. (eds.), Genomics and Molecular Genetics of Plant-Nematode Interactions, DOI 10.1007/978-94-007-0434-3 2, (C) Springer Science+Business Media B.V. 2011

Kraxner, F; Nilsson, S; Obersteiner, M (2003). Negative emissions from BioEnergy use, carbon capture and sequestration (BECS) - the case of biomass production by sustainable forest management from semi-natural temperate forests. Biom. Bioe. 24(4-5):285-296

Nyczepir, AP; Becker, JO (1998). Fruit and citrus trees. In: Barker, K.R., Pederson, G.A., Windham, G.L. (eds): plant and nematode interactions. American Society of Agronomy, Madison: 637684

Norton, DC (1978). Ecology of plant-parasitic nematodes. John Wiley and Sons Inc., USA, 268 $\mathrm{pp}$

Nyczepir, AP; Halbrendt, JM (1993). Nematode pests of deciduous fruit and nut trees. In: Evans, K; Trudgill, DL; Webster, JM (eds): Plant Parasitic Nematodes in Temperate Agriculture. CAB International, Wallingford: $381-425$

Olujobi, OJ (2016). Survey of trees and shrubs used for amenity purposes in Ekiti state. Inter. J. Res. Agric. F. Sci. 2 (2), paper-4:48-62 ISSN: 22082719

Omura, H (2004). Trees, forests and religion in Japan. Mount. Res. Develop. 24: 179-182

Onyekwelu, JC; Olaniyi, DB (2012). Socioeconomic importance of urban and peri-urban forests in Nigeria. In: research and capacity building for agricultural transformation in Nigeria (Adebayo et al, (eds)). Proceeding of $6^{\text {th }}$ annual conference of SAAT, FUTA, 7-9 ${ }^{\text {th }}$ Nov., $2012.200-210$

Panduro, TE; Veie, KL (2013). Classification and valuation of urban green spaces - A hedonic house price valuation. Land. Urb. Plan. 120: 119-128
Rosato, P; Breil, M; Giupponi, C; Berto, R (2017). Assessing the impact of urban improvement on housing values: a hedonic pricing and multiattribute analysis model for the historic centre of Venice. Buildings, 7(112): 1-24

Ruehle, JL (1967). Distribution of plant-parasitic nematodes associated with forest trees of the world. Southeastern Forest Experiment Station, Asheville, North Carolina. Forest Service, U.S. Dep. Agric. For. Serv. 156p

Ruehle, JL (1973). Nematodes and forest trees- types of damage to tree roots. Ann. Rev. Phytopathol 11:99-118

SAS (2007). Statistical Analysis System User's Guide. SAS Institute Inc. Carry N.C. USA

Shukla, RS; Chandel, PS (2014). A textbook of plant ecology including ethnobotany and soil science. S. Chand and Company Limited. India 512 pp

Ugbaja, UC (2018). Comparative studies of amenity trees in two universities, Port Harcourt. B.Sc. research project submitted to the Department of Forestry and Wildlife Management, Faculty of Agriculture, University of Port Harcourt. 59 pp.

Van Pelt, R (2001). Forest giants of the Pacific coast. Seattle: University of Washington Press

Whitehead, AG; Hemming, JR (1965). A comparison of some quantities methods of extraction small vermiform nematodes from soil. Ann. Appl. Biol. $55: 25-38$

William, E (2008). The importance of trees and nature in the community: a review of the relative literature. Arbor. Urb. For. 34(3):152-156.

Winter, LE; Brubaker, LB; Franklin, JF; Miller, EA; DeWitt, DQ (2002). Canopy disturbance over the five-century lifetime of an old-growth Douglas-fir stand in the Pacific Northwest. Can. J. For. Res. 32: $1057-1070$ 